\section{Nastamonu Eğitim Dergisi Kastamonu Education Journal}

Kasım 2019 Cilt:27 Sayı:6

kefdergi.kastamonu.edu.tr
Başvuru Tarihi/Received: 30.11 .2018

Kabul Tarihi/Accepted: 21.01.2019

DOI: $10.24106 /$ kefdergi.3445

\title{
Öğrenme Güçlüğü ile ilgili Türkiye'de Deneysel Olarak Yapılmış Tezlerin İncelenmesi
}

\section{Investigation of Experimental and Related to Specific Learning Disorder Thesis Written in Turkey}

\section{Öz}

\author{
Adnan ARI ${ }^{1}$, Ahmet YIKMIŞ², Osman ÖZOKÇU ${ }^{3}$
}

Öğrenme güçlüğü ile ilgili Türkiye'de deneysel olarak yapılmış olan tezlerinin incelenmesinin amaçlandığı bu araştırmada, nitel araştırma yaklaşımlarından betimsel tarama modeli kullanılmıştı. Yüksek Öğretim Kurumunun (YÖK) ulusal tez merkezi veri tabanı kullanılarak yapılan tarama sonucunda, deneysel olarak yapılmış sekiz çalışmaya ulaşıımıştır. Çalışmalar, katılımcıların özellikleri, bağımlı ve bağımsız değişkenler, araştırma modelleri ve ortam değişkenleri bağlamında incelenmiştir. İnceleme sonucunda, çalışmalardaki katlımcıların daha çok 5-16 yaş araIığında oldukları, yedi çalışmanın öğrenme güçlüğü olan bireylerle yapıldığı; uygulamaların en çok rehabilitasyon merkezlerinde gerçekleştiği, kontrol gruplu deneysel ve tek denekli araştirmaların araştırma deseni olarak kullanıldığı, tekrarlanan bağımlı ve bağımsız değişkenlerin kullanılmadığı ile ilgili bulgulara ulaşılmıştır.

Anahtar Kelimeler: deneysel araştırma, özel eğitim, öğrenme güçlüğü, tek denekli araştırma

\section{Abstract}

Descriptive survey model from qualitative research approaches has been used in this research, which aims to investigate experimental and specific learning disorder related thesis written in Turkey. As a result of the screening carried out using the national thesis center database of the Higher Education Institution (YÖK), eight experimental studies have been reached. The studies were examined in the context of participants' characteristics, dependent and independent variables, research models and environment variables. As a result of the study, it was determined that the participants in the studies were mostly in the 5-16 age range, and that the seven studies were conducted with individuals with specific learning disorder. Also it was found that most of the applications were performed in rehabilitation centers, and experimental with control groups and single-subject research were used as research design but repeated dependent and independent variables were not used.

Keywords: experimental research, single subject research, special education, specific learning disorder, 


\section{Extended Abstract}

Introduction: Different methods, techniques and strategies of teaching are used to resolve the difficulties of individuals with specific learning disorders (DSM-5, 2013, p.67-68) which are differently classified as severe, modarate, and mild learning disorders in terms of their learning difficulty in reading, math, and writing. In the reading area, guided reading, reading window, syllable reading (Quoted, Alegöz and Bala, 2017, p.78-101), phonological awareness training, Glass Analysis (Fisherman, 2017, p.190-193), TWA (thinking before reading, thinking while reading, and thinking after reading) (Palut, 2016, p.197-204); in the field of writing, cognitive strategy training, self-regulation (illker, 2017, p.217-219), error correction strategies (Palut, 2016, s.206-207); in mathematics field, methods, techniques, strategies and programs such as self-regulation, self-training, lets resolve, and graphical schema (Kalaç, 2017, p.265-269) are used. In Turkey, we encounter some master's and doctoral thesis which have been made experimentally with individuals with specific learning disorders are using some of these methods, techniques and strategies. This study was conducted because in Turkey there is no study on examining master's and doctoral thesis which have been made experimentally with individuals with specific learning difficulties.

\section{Purpose}

This research was carried out for the purpose of descriptive analysis of master's and doctoral thesis which are conducted experimentally about the specific learning disorders (which conducted with children with learning disabilities or with a risk of learning disabilities) in Turkey.

Research Model: In this research, descriptive survey model was used which is one of the qualitative research approaches. The studies conducted with individuals with specific learning disorders included in this study were determined according to some criteria. These criteria include: (a) to be made with individuals with specific learning disorders or those have the risk of learning difficulties, (b) being a doctoral or master's thesis conducted in Turkey, (c) as a research model to be used experimental research models and (d) to be made within the scope of education and training subject. The eight studies included in the study were examined in the context of the number, age, gender, diagnosis, and the grade of the participants, also distribution of studies by years, dependent and independent variables, research models of the studies, and environment variables in which the study was conducted.

Findings and Discussion: When the master and doctoral thesis related to specific learning disorders are examined; It was learned that 8 of thesis have a doctorate degree, 5 theses have a specialization in medicine and 57 thesis have a master degree and totally there are 70 thesis. Considering that the proportion of theses written in Turkey in the field of education and experimental studies is about $12 \%$, the ratio of total doctoral thesis is $11 \%$ and the ratio of $\mathrm{PhD}$ thesis which conducted in the field of education and designed experimentally is $3 \%$, it is thought that it is important to make more experimental studies in the field of education.

It has been learned that three of the research models are single-subject research; one of them is quasi-experimental and four of them are fully experimental. Two of the dependent variables study on mathematics (number perception, twostep mathematical verbal problem solving); one of them study on science (learning the subject of the solar system), one of them study on writing (writing the English names of numbers correctly); one of them study on reading (the number of correct words read per minute and number of incorrect reads); one of them study on visual perception; and the other two of them study on multiple skills (development of planning-attention-simultaneous successive function skills and psychomotor, perceptual, attention, memory, time concept; language, preparing for reading, writing, and mathematics, organizing, development of problem solving skills).

Referring to information about the independent variables; computer assisted education programs (education provided by computer assisted teaching materials, tablet computer-assisted, the program which includes "repetitive reading-pre-listening-feedback-reward" techniques of reading fluency treatment program), training programs (frosting visual perception training program, PASS: the cognitive training program including planning-attention-simultaneous-successive function skills and early intervention training program), diagram method and direct training, concurrent tip training, close-copy-compare teaching methods (in one study, the efficiency of the concurrent tip training and close-copy-compare training methods are compared) are used.

When the number of participants in the studies is examined, it is concluded that the number of participants is at least three, maximum 40 and the total number of participants in all studies is 109 . It was concluded that $69.7 \%$ of the participants were between the ages of 5-6 and participants aged 16 and over did not take part in the studies. When the individuals at risk of learning disorders or those who had been diagnosed with learning disorder receive the education at early age it can eliminate the reasons that will result in academic failures that will cause permanent problems in their academic and social lives (Balıkçı, 2017, p. 75). It was learned that 45 of the participants were female and 64 were male. It is important for the participants to have a close number of girls and boys in order to know whether the effectiveness of the strategies, teaching methods, techniques and training programs are differentiated by gender.

Only one study was performed with individuals at risk for specific learning disorders. It has been thought that preventions like recognition of individuals with special learning disorders at an early age and prevention of brain damage of these individuals, development of teaching skills of teachers, behavior control, teaching the skills of raising children to parents, can decrease the reasons of learning difficulties, protect the children against the factors causing learning difficulties (Fisherman, 2017 and pp.75-76) help the individuals to have less difficulty in their school life and help them to be successful at school.

| Kastamonu Eğitim Dergisi, 27(6), 2019| 


\section{Giriş}

Öğrenme güçlüğü teriminin ilk olarak 1962 yılında Kirk tarafından kullanılmaya başlamasından günümüze, öğrenme güçlüğüyle ilgili yapılan tanımlarda (Kirk, 1997; Özel Eğitim Hizmetleri Yönetmeliği, 2006) öğrenme güçlüğü olan bireylerin okuma, yazma, konuşma, dinleme gibi alanlarda güçlükler yaşadıkları belirtilmiştir.

Öğrenme güçlüğü olan bireylerin yaşadıkları güçlükleri önleme ve uygun programlardan yararlanmalarını sağlamak için erken yaşlarda tanılanmaları önemlidir. Öğrenme güçlüğü olan bireylerin tanı alması için a) kelimeleri yanlış, yavaş veya çaba sarf ederek okuma, b) okuduğunu anlama güçlüğü, c) yazma ile ilgili zorluklar, d) yazılı anlatımla ilgili güçlükler, e) sayı algısı, sayı gerçekleri ve hesaplamayı öğrenme güçlükleri f) matematiksel akıl yürütme ile ilgili zorluklar yaşamaları ve g) akademik becerileri öğrenme ve kullanmada yaşanan zorlukları-güçlükleri gidermeye dönük müdahaleler sağlanmasına rağmen bu güçlüklerden en az birinin alt aydır devam ediyor olması gerekmektedir. Bununla birlikte öğrenme güçlüğü tanısı koymak için, bireyin etkilenen akademik becerilerdeki performansının, yaş ortalamasının oldukça altında olması ve öğrenme güçlüklerinin okulun erken yıllarında kolayca gözlemlenmesi gerekmektedir (DSM5, 2013, s.66-67).

Özel eğitime ihtiyacı olan bireylerden olan öğrenme güçlüğü olan bireylerin tanı alması için de, formal ve informal değerlendirme araçları kullanılarak, bireyin yakınındaki kişilerle görüşmeler yapılarak ve bireyin doğrudan gözlenerek tanılamanın yapılması gerektiği vurgulanmıştır (Tuğrul-Kalaç, 2017, s.125). Öğrenme güçlüğü okuma (disleksi), matematik (diskalkuli), yazma (disgrafi) alanlarında zorluk yaşama durumuna göre ve ağır, orta, hafif düzey olarak farklı şekillerde sınıflandırılmaktadır. Öğrenme becerilerinde bir-iki akademik alanda bazı güçlükler yaşayan bireylerin hafif; öğrenme becerilerinde bir ya da daha fazla akademik alanda belirgin güçlükler yaşayan bireylerin orta ve öğrenme becerilerinde çeşitli akademik alanları etkileyen ağır-şiddetli güçlükler yaşayan bireylerin ağır düzeyde öğrenme güçlüğü olduğu belirtilmiştir (DSM-5, 2013, s.67-68).

Farklı şekillerde sınıflandırılan öğrenme güçlüğü tanısı almış olan bireyler okuma, yazma ve matematikte güçlükler yaşamaktadırlar. Okumada, ses, hece, kelime ve satır atlama; ses, hece ve kelime ekleme; seslerin sırasını değiştirme, harfleri ters çevirme, kelimenin tamamını tersten okuma, kelimelerin sırasını değiştirme; tekrar etme, sözcüğü hecelerine yanlış ayırma, akıcı okuyamama, kendi kendine düzeltme, yanlış okuma gibi güçlükler görülmektedir (Çıkılı, Alegöz ve Bala, 2017, s. 20-26). Yazmada, doğru yazma-harf harf yazma, dilbilgisi ve noktalamada doğruluk, yazılı ifadenin açıklığı veya organizasyonu gibi güçlükler bulunmaktadır. Matematikte ise, sayı algısı, aritmetik gerçeklerin ezberlenmesi, akıcı veya doğru hesaplama, matematiksel muhakemenin doğruluğu gibi güçlükler olduğu ifade edilmiştir (DSM-5, 2013, s.67).

Öğrenme güçlüğü olan bireylerin güçlük yaşadığı bu konularda gelişim gösterebilmeleri için farklı stratejiler, yöntemler, teknikler ve eğitim programları kullanılmaktadır. Okuma alanında rehberli okuma, koro halinde okuma, eşli okuma, akran okuma, ahenkli okuma, kelimenin sonunu ya da başını yuvarlak içerisine alma, renklendirme, kelimeyi şekil olarak belirleme, hecelerine ayırarak okuma, parmakla ya da kalemle takip, nokta koyarak okuma, kelimelerin altını çizerek okuma, kelime tekrar tekniği ve okuma penceresi gibi yöntem, teknik ve stratejiler kullanılmaktadır. (Çıkılı, Alegöz ve Bala, 2017, s.78-101). Bunların dışında akıcılığı destekleme, tekrarlı okuma, akran yardımıyla öğretim, karşılıklı öğretim, anlama yöntemleri, okumada ustalık ve düzeltici okuma programı, okumayı iyileştirme, sesbilgisel farkındalık eğitimi, programlanmış okuma eğitimi, çok duyulu okuma yöntemleri, nörolojik etki yöntemi, Glass analizi gibi yöntem ve teknik ve stratejilerin de kullanıldığı görülmektedir (Balıkçı, 2017, s.190-193).

Yazma alanında da iyileştirme stratejileri, dengeleme stratejileri, bilişsel strateji öğretimi, kendini düzenleme strateji gelişimi modeli (ilker, 2017, s.217-219), çocukların yazım hatalarını kopyalaması ve doğru sunumun model olarak gösterilmesi; kısa bir zaman bekledikten sonra doğru yazımın gösterilmesi; kelimelerde yer alan harflerin yapılarına odaklanma eğitimi stratejisi, hata düzeltme stratejileri (Palut, 2016, s.206-207) kullanılmaktadır.

Matematik alanında ise, kendini düzenleme, kendi kendine öğretim, hadi çözümle, on sayısına köprüleme, hatılatıcı ipucu, zihinsel görüntü oluşturma, grafik şeması (Kalaç, 2017, s.265-269) gibi strateji, yöntem, teknik ve programlar kullanılmaktadır.

Bu stratejiler, yöntemler, teknikler ve eğitim programları kullanılarak yapılan deneysel çalışmalar ile, öğrenme güçlüğü olan bireylere güçlük yaşadıkları alanlarda ve yeni becerileri öğretmede etkili olup olmadıkları, hangisinin diğerlerine göre daha verimli olduğu anlaşılabilir. Bu amaçlar doğrultusunda, Türkiye'de öğrenme güçlüğü olan bireylerle deneysel olarak yapılmış olan yüksek lisans ve doktora tezleri olduğu (Doğan, 2012; Doğmaz, 2016; Erdem-Özat, 2010; İlik, 2009; Kançeşme, 2015; Mutlu, 2016; Özbek, 2014; Ün, 2009) görülmüştür. 
Ayrıca, öğrenme güçlüğü olan bireylerle yapılmış olan çalışmaların betimsel olarak incelendiği araştırmalara da rastlanmıştır. Örneğin, ilköğretim döneminde öğrenme güçlüğü olan öğrencilerin yazma becerileriyle ilgili (illker ve Melekoğlu, 2017; Özer-Şanal ve Erdem, 2017), okuma güçlüğünde teknoloji kullanımıyla ilgili çalışmalar (Bilal-Özbek, 2015) ve ülkemizde öğrenme güçlüğü ile ilgili olarak 1972-2011 yılları arasında yapılan tarama, deneysel modelli çalışmalar ve vaka örnekleri incelenmiştir (Özkardeş, 2012).

Türkiye'de öğrenme güçlüğü olan bireylerle deneysel olarak yapılmış olan yüksek lisans ve doktora tezlerini inceleyen bir çalışmaya rastlanmaması bu çalışmanın yapılmasını gerekli kılmıştır. Bu gereksinim çerçevesinde yapılan bu araştrrma, öğrenme güçlüğü ile ilgili (öğrenme güçlüğü olan veya öğrenme güçlüğü riski taşıyan bireylerle yapılmış olan) Türkiye'de deneysel olarak yapılmış olan yüksek lisans ve doktora tezlerini betimsel olarak incelemeyi amaçlanmıştır. Bu amaç doğrultusunda aşağıda yer alan alt sorulara yanıt aranmıştır;

1. Çalışmalarda yer alan katılımcıların sayı, yaş, cinsiyet, tanı, devam ettikleri sınıf değişkenleri nedir?

2. Çalışmaların türü (yüksek lisans ve doktora tezi) nedir?

3. Çalışmaların yıllara göre dağııımı nasıldır?

4. Çalışmalarda uygulamanın gerçekleştirildiği ortamlar nelerdir?

5. Çalışmalarda kullanılan araştırma modelleri nelerdir?

6. Çalışmalarda yer alan bağımlı değişkenler nelerdir?

7. Çalışmalarda yer alan bağımsız değişkenler nelerdir?

\section{Yöntem}

Öğrenme güçlüğü olan veya öğrenme güçlüğü riski taşıyan bireylerle deneysel olarak yapılmış olan yüksek lisans ve doktora tezlerini incelemeyi amaçlayan ve nitel araştırma yaklaşımlarından betimsel tarama modelinin kullanıldığı bu araştırmada yer verilen çalışmalar, bazı ölçütlere göre belirlenmiştir. Bu ölçütler: (a) Öğrenme güçlüğü olan veya öğrenme güçlüğü riski taşıyan bireylerle yapılmış olması, (b) Türkiye'de yapılmış doktora ve yüksek lisans tezi olması, (c) Araştırma modeli olarak deneysel araştırma modellerinin kullanmış olması ve (d) eğitim-öğretim konusunda yapılmış olması.

Metodolojik değerlendirme yönteminin kullanıldığı bu çalışmada, belirlenen ölçütler doğrultusunda yapılmış çalışmalara ulaşmak amacıyla, "öğrenme güçlüğü, "özgül öğrenme güçlüğü", "özel öğrenme güçlüğü" anahtar sözcükleri kullanılarak ulusal tez merkezi akademik veri tabanından tüm doktora ve yüksek lisans tezleri taranmıştr. Yapılan taramalar sonucunda, belirlenen ölçütlere göre öğrenme güçlüğü olan veya öğrenme güçlüğü riski taşıyan bireylerle deneysel olarak yapılmış toplam 9 teze ulaşılmış, fakat bir doktora tezine erişim engeli nedeniyle 2 doktora tezi ve 6 yüksek lisans tezi olmak üzere 8 tez çalışmanın kapsamına alınmıştır.

\section{Betimsel Analiz}

Incelemeye dahil edilen sekiz çalışma, çalışmalardaki katılımcıların sayısı, yaşı, cinsiyeti, tanısı, devam ettikleri sınıfı, çalışmaların yıllara göre dağııımı, çalışmanın bağımlı ve bağımsız değişkenleri, çalışmalardaki araştırma modelleri ve çalışmanın yapıldığı ortam değişkenleri bağlamında incelenmiştir. Burada ifade edilenlerle ilgili bilgiler Tablo 1'de gösterilmiştir.

\section{Sınırlılıklar}

Yapılan bu çalışmanın sınırlııkları arasında, sadece Türkiye'de öğrenme güçlüğü ile ilgili deneysel olarak yapılmış olan yüksek lisans ve doktora tezlerini içermesi ve öğrenme güçlüğü ile ilgili deneysel olarak yapılmış makaleleri içermemesi yer almaktadır. 
Tablo 1. Öğrenme Güçlüğü olan Bireylerle Yapılmış Deneysel Çalışmaların Demografik Bilgileri

\begin{tabular}{|c|c|c|c|c|c|c|c|c|c|c|}
\hline \multirow{2}{*}{\multicolumn{2}{|c|}{ Çalışma Adı }} & \multirow{3}{*}{$\begin{array}{c}\text { Tez } \\
\text { Türü } \\
\text { Dr }\end{array}$} & \multicolumn{4}{|c|}{ Katılımcı özellikleri } & \multirow[b]{2}{*}{ Ortam } & \multirow[b]{2}{*}{ Bağımlı değişken } & \multirow[b]{2}{*}{ Bağımsız değişken } & \multirow[b]{2}{*}{ Araştırma modeli } \\
\hline & & & Sayı & Cinsiyet & Yaş & Sınıf & & & & \\
\hline $\begin{array}{l}\text { Mutlu, } \\
\text { (2016) }\end{array}$ & Y. & & 3 & $\begin{array}{l}1 \mathrm{~K} \\
2 \mathrm{E}\end{array}$ & 9 & 3. & Okul & $\begin{array}{l}\text { Sayı Algılama Be- } \\
\text { cerileri }\end{array}$ & $\begin{array}{l}\text { Bilgisayar Destekli } \\
\text { Öğretim Materyal- } \\
\text { leri ile Verilen Eği- } \\
\text { tim }\end{array}$ & $\begin{array}{l}\text { Ön-Test, Son-Testli Tek } \\
\text { Denekli Yarı Deneysel } \\
\text { Desen }\end{array}$ \\
\hline $\begin{array}{l}\text { Doğmaz, } \\
(2016)\end{array}$ & S. & YL & $\begin{array}{l}10 \mathrm{DG} \\
10 \mathrm{KG}\end{array}$ & $\begin{array}{l}7 \mathrm{~K}-3 \mathrm{E} \\
8 \mathrm{~K}-2 \mathrm{E}\end{array}$ & $\begin{array}{l}10- \\
14\end{array}$ & 3.-8. & $\begin{array}{l}\text { Reh. } \\
\text { Mer. }\end{array}$ & $\begin{array}{l}\text { İki Basamaklı } \\
\text { Mat e matikse I } \\
\text { Sözel Problem } \\
\text { Çözme Becerileri }\end{array}$ & Diyagram Yöntemi & $\begin{array}{l}\text { Ön-test, Son-Test } \\
\text { Deney-Kontrol Gruplu } \\
\text { Deneysel Desen }\end{array}$ \\
\hline $\begin{array}{l}\text { Kançeşme, } \\
\text { (2015) }\end{array}$ & C. & YL & 4 & $\begin{array}{l}2 \mathrm{~K} \\
2 \mathrm{E}\end{array}$ & $9-11$ & $3 .-5$. & $\begin{array}{l}\text { Reh. } \\
\text { Mer. }\end{array}$ & $\begin{array}{l}\text { 0-1-2-3-4-5-6-7-8- } \\
9 \text { Rakamlarının İn- } \\
\text { gilizcelerini Doğru } \\
\text { Olarak Yazma }\end{array}$ & $\begin{array}{l}\text { Eşzamanlı İpucuyla } \\
\text { Öğretim Yöntemi } \\
\text { ve Kapat-Kopya- } \\
\text { la-Karşılaştır Yön- } \\
\text { temi }\end{array}$ & $\begin{array}{l}\text { Dönüşümlü Uygula- } \\
\text { malar Modeli }\end{array}$ \\
\hline $\begin{array}{l}\text { Özbek, A. } \\
(2014)\end{array}$ & B. & YL & 3 & $\begin{array}{l}1 \mathrm{~K} \\
2 \mathrm{E}\end{array}$ & $8-9$ & $2 .-3$. & $\begin{array}{l}\text { Reh. } \\
\text { Mer. }\end{array}$ & $\begin{array}{l}\text { Bir Dakikada Oku- } \\
\text { nan Doğru Kelime } \\
\text { Sayısı ve Hatalı } \\
\text { Okuma Sayısı }\end{array}$ & $\begin{array}{l}\text { Tablet Bilgisayar } \\
\text { Destekli, "Tekaralı } \\
\text { Okuma-Önceden } \\
\text { Dinleme-Geribil- } \\
\text { dirim-Ödül”" Tek- } \\
\text { niklerini İçeren } \\
\text { Okuma Akıcılığı Sa- } \\
\text { ğaltım Programı }\end{array}$ & $\begin{array}{l}\text { Deneklerarası Çoklu } \\
\text { Başlama Modeli }\end{array}$ \\
\hline $\begin{array}{l}\text { Doğan, } \\
\text { (2012) }\end{array}$ & H. & $\mathrm{Dr}$ & $\begin{array}{l}20 \mathrm{DG} \\
20 \mathrm{KG}\end{array}$ & $\begin{array}{l}7 \mathrm{~K}-13 \mathrm{E} \\
8 \mathrm{~K}-12 \mathrm{E}\end{array}$ & $5-6$ & $\begin{array}{l}\text { Ana } \\
\text { Sinıfi }\end{array}$ & Okul & $\begin{array}{l}\text { Psikomotor, Algı- } \\
\text { sal, Dikkat, Bellek, } \\
\text { Zaman Kavramı, } \\
\text { Dil, Okumaya-Yaz- } \\
\text { maya-Matema- } \\
\text { tiğe Hazırlık, Or- } \\
\text { ganize Etme ve } \\
\text { Problem Çözme } \\
\text { Becerilerinin Ge- } \\
\text { lişimi }\end{array}$ & $\begin{array}{l}\text { Erken Müdahale } \\
\text { Eğitim Programı }\end{array}$ & $\begin{array}{l}\text { Ön-test, Son-Test } \\
\text { Deney-Kontrol Gruplu } \\
\text { Deneysel Desen }\end{array}$ \\
\hline $\begin{array}{l}\text { Erdem-Öza } \\
\text { N. (2010) }\end{array}$ & & YL & $\begin{array}{l}10 \mathrm{DG} \\
10 \mathrm{KG}\end{array}$ & $\begin{array}{l}4 \mathrm{~K}-6 \mathrm{E} \\
4 \mathrm{~K}-6 \mathrm{E}\end{array}$ & $5-6$ & $1 .-2$ & RAM & $\begin{array}{l}\text { Görsel Algı Geli- } \\
\text { şimi (el-göz ko- } \\
\text { ordinasyonu, şe- } \\
\text { kil-zemin algısı, } \\
\text { algı sabitliği, me- } \\
\text { kan-zemin algısı, } \\
\text { mekansal ilişkiler } \\
\text { algısı) }\end{array}$ & $\begin{array}{l}\text { Frostig Görsel Algı } \\
\text { Eğitim Programı }\end{array}$ & $\begin{array}{l}\text { Ön-test, Son-Test } \\
\text { Deney-Kontrol Gruplu } \\
\text { Deneysel Desen }\end{array}$ \\
\hline Ün, D. (2009 & & YL & $\begin{array}{l}8 \mathrm{DG} \\
8 \mathrm{KG}\end{array}$ & $\begin{array}{l}1 \mathrm{~K}-7 \mathrm{E} \\
1 \mathrm{~K}-7 \mathrm{E}\end{array}$ & 6 & 1. & Okul & $\begin{array}{l}\text { Plan I a ma-Dik- } \\
\text { kat-Eşzamanlı-Ar- } \\
\text { dıl İşlev Becerileri- } \\
\text { ni Geliştirme }\end{array}$ & $\begin{array}{l}\text { Pla n I a ma - D ik- } \\
\text { kat-Eşzamanlı-Ardıl } \\
\text { İşlev Becerilerini } \\
\text { İçeren Bilişsel Eği- } \\
\text { tim Programı }\end{array}$ & $\begin{array}{l}\text { Ön-test, Son-Test } \\
\text { Deney-Kontrol Gruplu } \\
\text { Deneysel Desen }\end{array}$ \\
\hline $\begin{array}{l}\text { İlik, Ş. } \\
(2009)\end{array}$ & Ş. & YL & 3 & $\begin{array}{l}1 \mathrm{~K} \\
2 \mathrm{E}\end{array}$ & $\begin{array}{l}14- \\
14- \\
15\end{array}$ & $\begin{array}{l}\text { 7. (2) } \\
\text { 8. (1) }\end{array}$ & $\begin{array}{l}\text { Reh. } \\
\text { Mer. }\end{array}$ & $\begin{array}{l}\text { Fen Bilgisi dersin- } \\
\text { de güneş sistemi } \\
\text { konusunun öğre- } \\
\text { timi }\end{array}$ & $\begin{array}{l}\text { Doğrudan Öğretim } \\
\text { Yöntemi }\end{array}$ & $\begin{array}{l}\text { Yoklama Evreli Çoklu } \\
\text { Yoklama Modeli }\end{array}$ \\
\hline
\end{tabular}

DG: Deney Grubu / KG: Kontrol Grubu / YL: Yüksek Lisans / Dr: Doktora / K: Kız / E: Erkek / RAM: Rehberlik ve Araşttrma Merkezi / Reh. Mer.: Rehabilitasyon Merkezi 


\section{Bulgular}

Belirlenen ölçütler doğrultusunda sekiz çalışma incelenmiştir. Çalışmaların incelenmesi sonucunda kathlımcıların sayı-yaş-cinsiyet-tanı-devam ettikleri sınıf, çalışmaların türü, çalışmaların yıllara göre dağılımı, çalışmaların gerçekleştirildiği ortam, çalışmalarda kullanılan araştırma modeli, bağımlı ve bağımsız değişkenler ile ilgili bilgilere bulgular kısmında yer verilmiştir.

\section{Katılımcı Özellikleri (sayı, yaş, cinsiyet, tanı, devam ettikleri sınıf)}

Kathlımcı özellikleri olarak çalışmalara katılan katılımcı sayısı, katılımcıların cinsiyeti, yaşı ve devam ettikleri sınıf ile ilgili bilgiler incelenmiştir. Çalışmalardaki katılımcı sayısına bakıldığında, katılımcı sayısının en az üç, en fazla 40 olduğu ve tüm çalışmalardaki toplam katılımcı sayısının 109 olduğu sonucuna ulaşılmıştır. Çalışmalardaki katılımcı sayısı ile ilgili bilgilere Tablo 2'de yer verilmiştir.

Tablo 2. Çalışmalara katılan katılımcıların sayısı

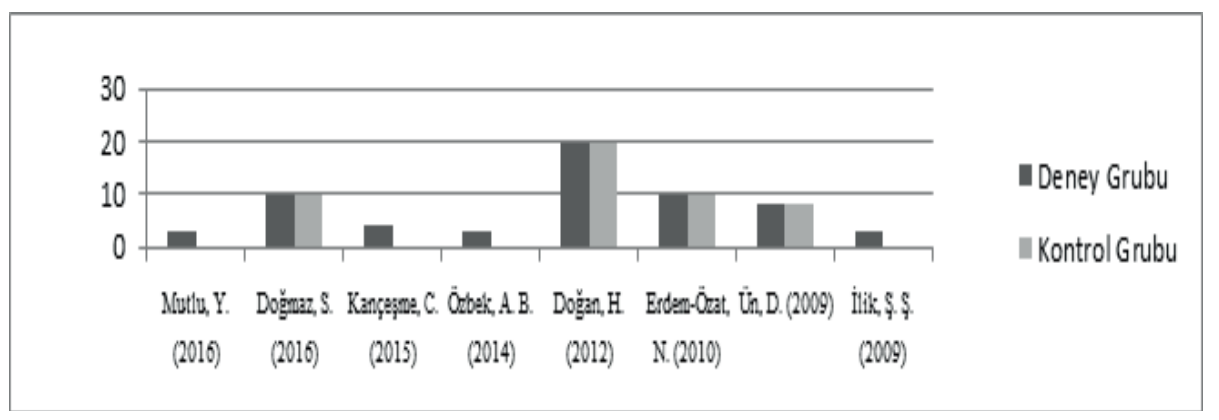

Çalışmalarda yer alan katılımcılar, yaş değişkeni açısından incelendiğinde katılımcıların 5-15 yaş aralığında olduğu bilgisine ulaşılmıştır. Katllımcıların \% 69,7'sının 5-6 yaş aralığında olduğu ve 16 yaş ve üstü katlımcıların çalışmalarda yer almadığı sonuçlarına ulaşılmıştır. Katılımcıların yaşı ile ilgili bilgilere Tablo 3'te yer verilmiştir.

Tablo 3. Katılımcıların yaşı

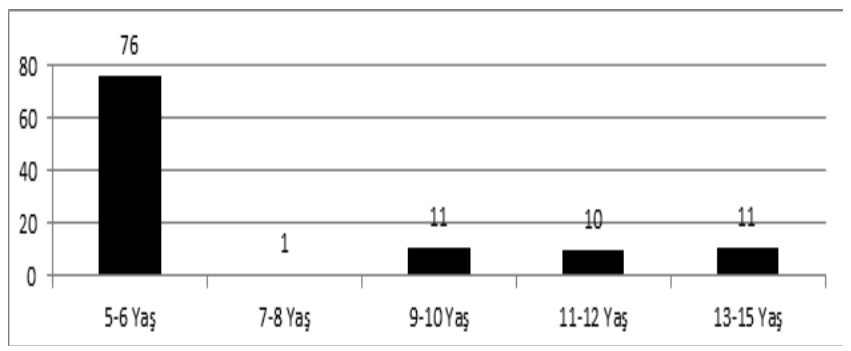

Yapılan çalışmaların, cinsiyet değişkenine göre incelenmesi sonucunda çalışmalara katılan katılımcıların $45^{\prime}$ inin kız ve 64'ünün ise erkek olduğu bilgisine ulaşılmıştır. Çalışmalara katılan katılımcıların cinsiyeti ile ilgili bilgilere Tablo 4'te yer verilmiştir.

\section{Tablo 4. Katilımcıların cinsiyeti}

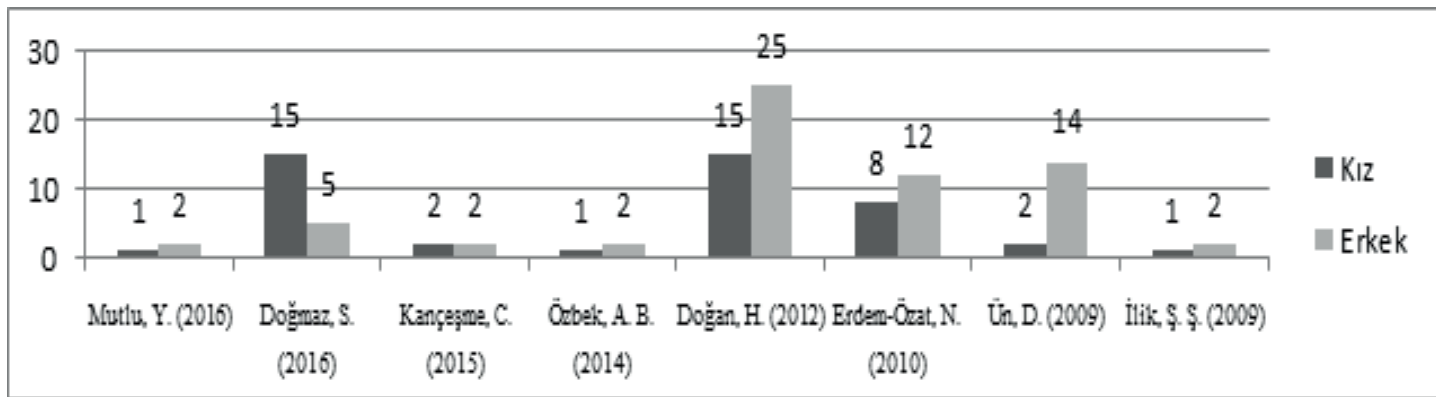

Çalışmalarda yer alan kathlımcılar, öğrenme güçlüğü tanısı almış olma veya öğrenme güçlüğü riski taşıma durumlarına göre incelendiğinde sadece bir çalışmada öğrenme güçlüğü riski taşıyan bireylerle çalışıldığı ve diğer çalışmaların tamamında ise öğrenme güçlüğü tanısı almış olan bireylerle çalışıldığı sonucuna ulaşılıı̧tır. Kattımcıların öğrenme güçlüğü tanısı almış olma veya öğrenme güçlüğü riski taşıma durumları ile ilgili bilgilere Tablo 5 'te yer verilmiştir. 
Tablo 5. Kathlımcıların öğrenme güçlügü tanısı almış olma ya da öğrenme güçlüğü riski taşıma durumları

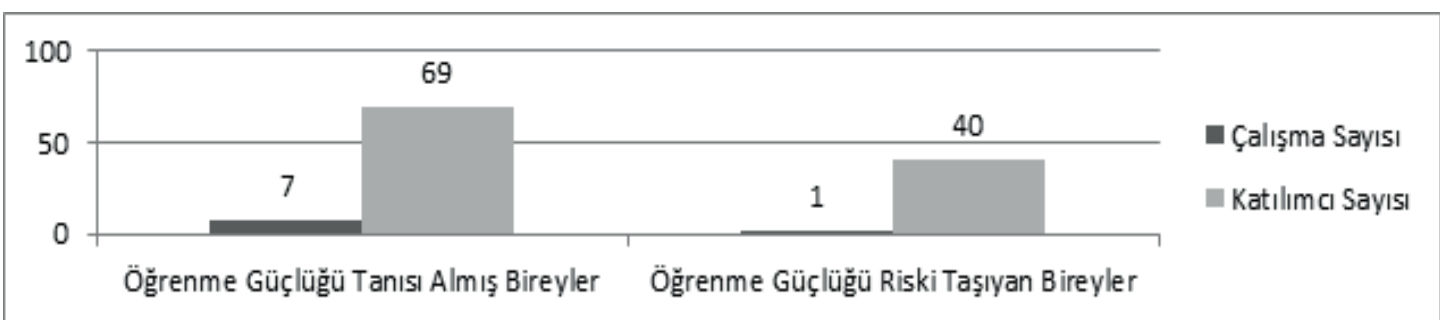

Çalışmalarda yer alan öğrenme güçlüğü tanısı almış veya öğrenme güçlüğü riski taşıyan katılımcıların devam ettikleri sınıf değişkeni incelendiğinde, kathlımcıların ana sınıfi, birinci-ikinci-üçüncü-dördüncü-beşinci-altıncı-yedinci ve sekizinci sınıfa devam ettikleri; en fazla katılımcının ana sınıfinda ve en az katılımcının 4.-8. sınıfta eğitime devam eden bireyler oldukları sonucuna ulaşılmıştır. Katılımcıların devam ettikleri sınıf ile ilgili bilgilere Tablo 6'da yer verilmiştir.

Tablo 6. Katılımcıların devam ettikleri sınıf

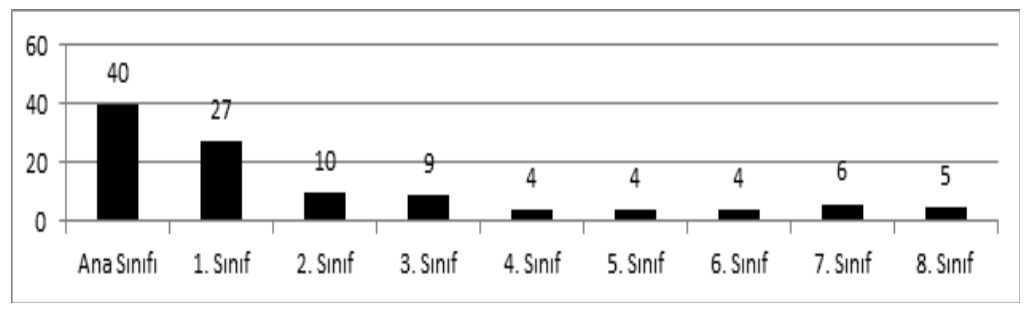

\section{Çalışmaların Türü}

İncelenen çalışmaların türü ile ilgili bilgilere bakıldığında, çalışmalardan beş tanesinin yüksek lisans; iki tanesinin ise doktora tezi olduğu ile ilgili bilgilere ulaşılmıştır. Çalışmaların türü ile ilgili bilgilere Tablo 7'de yer verilmiştir.

Tablo 7. Çalışmaların türü

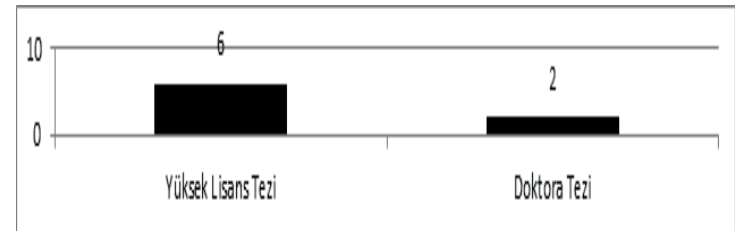

\section{Çalışmaların Yıllara Göre Dağılımı}

Öğrenme güçlüğü ile ilgili deneysel olarak yapılan yüksek lisans ve doktora tezleri incelendiğinde, ilk çalışmanın 2009 ve son çalışmanın ise 2016 yılında yapıldığı ile ilgili bulgulara ulaşılmıştı. Ayrıca, öğrenme güçlüğü ile ilgili deneysel olarak yapılan çalışmaların sistematik bir şekilde geçmişten günümüze artş̧ göstermediği de görülmüştür. Öğrenme güçlüğü ile ilgili deneysel olarak yapılmış olan yüksek lisans ve doktora tezlerinin yıllara göre dağılımı ile ilgili bilgilere Tablo 8' de yer verilmiştir.

Tablo 8. Çalışmaların yıllara göre dağılımı

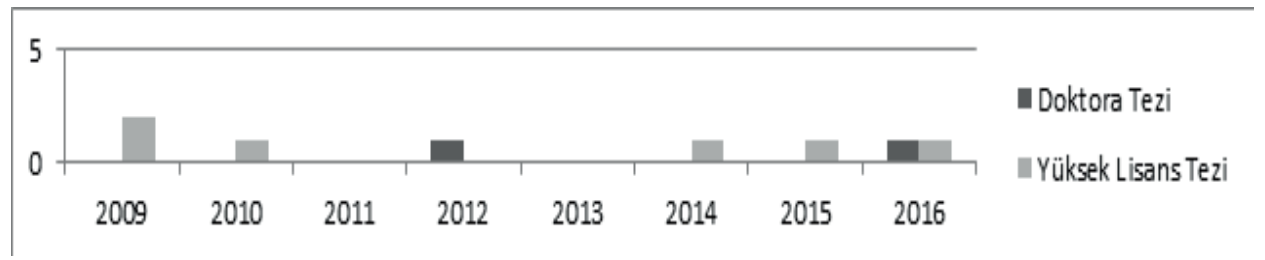

\section{Uygulamanın Gerçekleştirildiği Ortam}

Çalışmalarda yer alan hedef davranışların öğretiminin gerçekleştirildiği ortam ile ilgili bilgiler incelendiğinde üç çalışmanın okul ortamında (bireysel eğitim ortamında, toplantı odasında gibi); dört çalışmanın Rehabilitasyon Merkezinde (bireysel eğitim sınıfı-odası gibi); bir çalışmanın da Rehberlik Araştırma Merkezi'de gerçekleştirildiği ile ilgili bilgilere ulaşılmıştır. Uygulamanın gerçekleştirildiği ortamla ilgili bilgilere Tablo 9'da yer verilmiştir. 
Tablo 9. Uygulamanın gerçekleştirildiği ortam

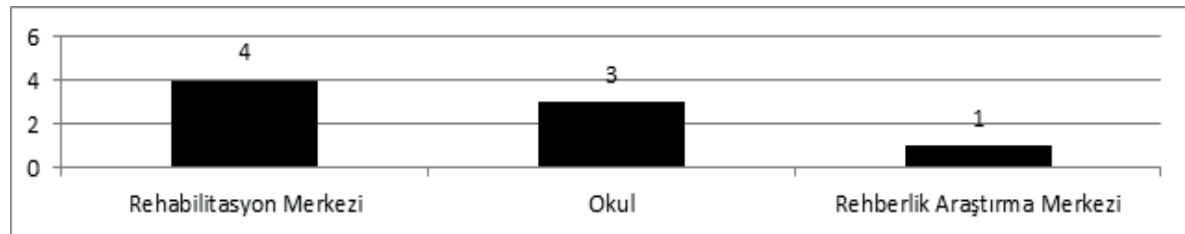

\section{Çalışmalarda Kullanılan Araştırma Modelleri}

Öğrenme güçlüğü olan veya öğrenme güçlüğü riski taşıyan bireylerle deneysel olarak yapılmış yüksek lisans ve doktora tezi olan çalışmalarda kullanılan araştırma modellerinin üç tanesinin tek denekli araştırma; bir tanesinin yarı deneysel ve dört tanesinin ise tam deneysel olarak yapıldığı bilgisine ulaşılmıştır. Tek denekli araştırma modellerinden yoklama evreli çoklu yoklama, denekler arası çoklu başlama ve dönüşümlü uygulamalar modellerinin kullanıldığı gözlemlenmiştir. Çalışmalarda kullanılan araştırma modelleri ile ilgili bilgilere Tablo 10 'da yer verilmiştir.

Tablo 10. Çalışmalarda kullanılan araştırma modeli

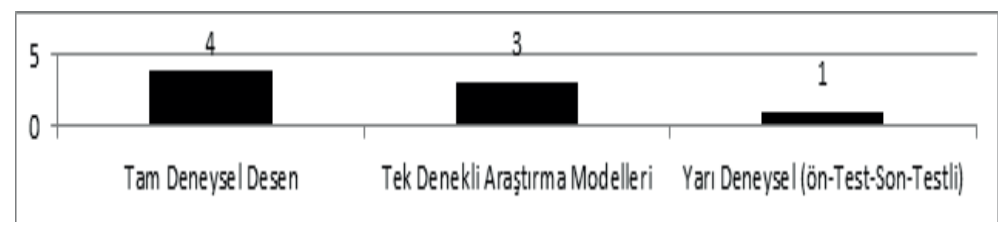

\section{Çalışmalarda Yer Alan Bağımlı Değişkenler}

Öğrenme güçlüğü olan veya öğrenme güçlüğü riski taşıyan bireylerle deneysel olarak yapılmış olan yüksek lisans ve doktora tezlerinde yer alan bağımlı değişken ile ilgili bilgilere bakıldığında bağımlı değişkenlerden iki tanesinin matematiği (sayı algılama, iki basamaklı matematiksel sözel problem çözme); bir tanesinin fen bilgisini (güneş sistemi konusunu öğrenme), bir tanesinin yazmayı (rakamların İngilizce adlarını doğru yazma); bir tanesinin okumayı; bir tanesinin görsel algıyı ve diğer ikisinin birden fazla beceriyi (planlama-dikkat-eşzamanlı ardıl işlev becerileri geliştirme ve psikomotor-algısal-dikkat-bellek-zaman kavramı-dil-okumaya-yazmaya-matematiğe hazırlık-organize etme-problem çözme becerilerinin gelişimi) konu edindiği ile ilgili bilgilere ulaşılmıştır. Çalışmalarda yer alan bağımlı değişkenlerin konularına göre dağııımı ile ilgili bilgilere Tablo 11 'da yer verilmiştir.

Tablo 11. Çalışmalardaki bağımlı değişkenlerin konularına göre dağılımı

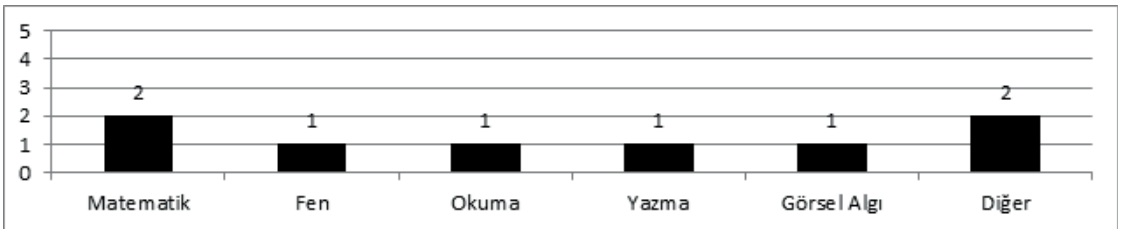

\section{Çalışmalarda Yer Alan Bağımsız Değişkenler}

İncelenen çalışmalarda bağımsız değişken olarak bilgisayar destekli eğitim programlarının (bilgisayar destekli öğretim materyalleri ile verilen eğitim, tablet bilgisayar destekli, "tekrarlı okuma-önceden dinleme-geribildirim-ödül" tekniklerini içeren okuma akıcılığı sağaltım programı), eğitim programlarının (frostig görsel algı eğitim programı, PASS: planlama-dikkat-eşzamanlı-ardıl işlev becerilerini içeren bilişsel eğitim programı ve erken müdahale eğitim programı), diyagram, doğrudan öğretim, eşzamanlı ipucuyla öğretim, kapat-kopyala-karşılaştı öğretim yöntemlerinin kullanıldığı görülmüştür. Çalışmalarda bağımlı değişken üzerindeki etkisi incelenen bağımsız değişkenlerle ilgili bilgilere Tablo 12 'de yer verilmiştir.

Tablo 12. Çalışmalarda etkililiği sınanan bağımsız değişkenler

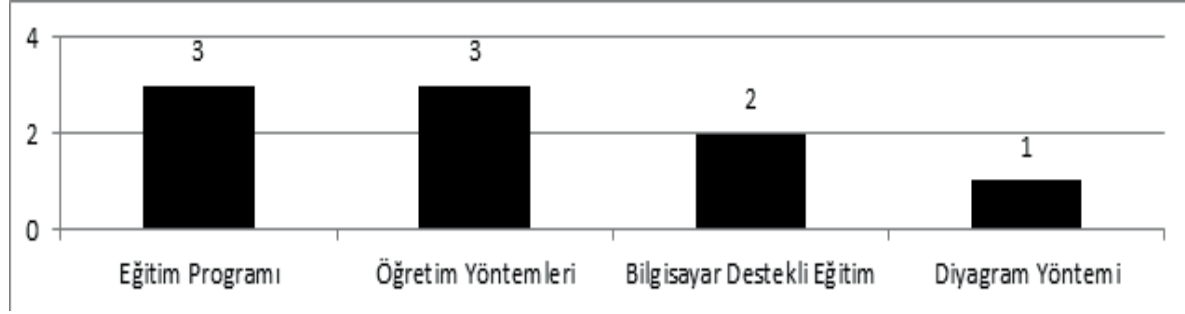

| Kastamonu Eğitim Dergisi, 27(6), 2019| 


\section{Tartışma}

Öğrenme güçlüğü olan veya öğrenme güçlüğü riski taşıyan bireylerle deneysel olarak yapılmış olan yüksek lisans ve doktora tezlerini inceleme amacıyla yapılan bu çalışmada, katıımcıların sayı, yaş, cinsiyet, tanı ve devam ettikleri sınıf, çalışmaların türü, çalışmalarda kullanılan araştırma desenleri, bağımlı ve bağımsız değişkenler, uygulamaların gerçekleştirildiği ortamlar ve çalışmaların yıllara göre dağılımı incelenmiştir.

Öğrenme güçlügü ile ilgili yapılmış olan yüksek lisans ve doktora tezlerindeki katılımcı sayılarına bakıldığında kontrol gruplu deneysel desenin kullanıldığı çalışmalarda katılımcı sayısı (Doğan, 2012; Doğmaz, 2016; Erdem-Özat, 2010; Ün, 2009), tek denekli araştırma modellerinin kullanıldığı araştırmalara (ilik, 2009; Kançeşme, 2015; Özbek, 2014) göre daha fazla bulunmuştur.

Çalışmalarda yer alan katıımcıların yaşı ve devam ettikleri sınıf ile ilgili bilgilere bakıldığında, katılımcıların \% 69,7'sinin 5-6 yaş aralığında olduğu ve \% 61'inin anasınıf ve ilkokul birinci sınıfa devam ettiği, lise ve üniversite eğitimi alan 16 yaş ve üstü bireylerin çalışmalarda yer almadığı görülmüştür. Bu bilgi iki açıdan değerlendirilebilir. Birincisi öğrenme güçlüğü riski taşıyan veya öğrenme güçlüğü tanısı almış olan bireylerin erken yaşlarda eğitim alması onların akademik ve sosyal hayatlarında kalıı problemlere yol açacak akademik başarısızlıklarla sonuçlanacak nedenleri ortadan kaldırabilecektir (Balıkçı, 2017, s. 75). İkinci olarak, erken yaşlarda gerekli önlemlerin alınması, öğrenme güçlüğü olan bireylerin yaşadıkları güçlükleri azaltmak ve ortadan kaldırmak için strateji-yöntem-eğitim programlarını kullanmak her ne kadar önemliyse, lise ve sonrası için de gerekli müdahale programlarının uygulanması, öğrenme güçlüğü olan bireylerin üniversite programlarına katılımını sağlaması açısından da önemlidir. Dolayısıyla öğrenme güçlüğü olan bireylerle de deneysel olarak çalışmaların yapılması önemlidir. Ayrıca çalışmalarda yer alan katılımcıların \% 41'ini kız ve \% 59'unu erkek oluşturmuştur. Yapılacak olan deneysel araştırmalarda yer alacak katılımcıların kız ve erkek sayılarının birbirine yakın olarak seçilmesi uygulanan stratejilerin, öğretim yöntemlerinin, tekniklerin ve eğitim programlarının etkililiğinin cinsiyete göre farklılaşıp-farklılaşmadığını gösterebilmesi açısından önemli olabileceği düşünülmektedir.

Yapılan çalışmalarda yer alan katılımcıların öğrenme güçlüğü tanısı almış olma veya öğrenme güçlüğü riski taşımış olma bağlamında incelendiğinde, sadece bir çalışmanın öğrenme güçlüğü riski taşıyan bireylerle yapıldığı bilgisine ulaşılmıştır. Öğrenme güçlüğü riski taşıyan bireylerin erken yaşlarda fark edilmeleri öğretmenlerin öğretim becerilerini geliştirme, davranış kontrolü, ebeveynlere çocuk yetiştirme becerilerini öğretme gibi önlemlerin, öğrenme güçlüklerinin nedenlerinin azalmasına, öğrenme güçlüğüne neden olan etmenlere karşı çocukların korunmasına (Balıkçı, 2017, s.7576) ve bu bireylerin okul yaşamlarında daha az güçlükle karşılaşmalarına ve başarılı olmalarına yardımcı olacaktır.

Öğrenme güçlüğü ile ilgili farklı disiplinlerde yapılmış tezlerin yıllara göre dağılımı ile ilgili bilgilere bakıldığında, ilk tezin 1996 ve son tezin 2017 yıllarında olduğu; 8 tezin doktora, 5 tezin tıpta uzmanlık, 57 tezin ise yüksek lisans tezi olmak üzere toplam tez sayısının 70 olduğu bilgisine ulaşılmıştı. Eğitim alanında ve deneysel olarak yapılan çalışma oranının yaklaşık \% 12 olması, toplam doktora tez oranının \% 11 ve eğitim alanında deneysel olarak yapılmış doktora tez oranının ise yaklaşık \% 3 olduğu görülmüştür. Bu bilgiler bağlamında eğitim alanında ve deneysel olarak daha fazla çalışmanın yapılmasının önemli olduğu düşünülmektedir.

Çalışmalarda yer alan katıımcılarla gerçekleştirilen tek denekli araştırma modellerinin kullanıldığı uygulamaların rehabilitasyon merkezlerinde ve kontrol gruplu deneysel desenlerin kullanıldığı uygulamaların ise genellikle okullarda yapıldığı görülmüştür. Tek denekli araştırma modellerinin kullanıldığı uygulamaların okullarda da gerçekleştirilmesi ve bunun için uygun ortamların sağlanmasının daha çok çocuğa ulaşılmasını kolaylaştıracağı düşünülmektedir. Hangi strateji-teknik-yöntem ve eğitim programının öğrenme güçlüğü olan bireylerin yaşadıkları güçlükleri giderme anlamında etkili olduğunu belirlemek amacıyla deneysel çalışmaların daha çok yapılması gerekliliği düşünülmektedir.

Çalışmalarda yer alan bağımlı değişkenlerin; sayı algılama, iki basamaklı matematiksel sözel problem çözme, güneş sistemi konusunu öğrenme, rakamların İngilizce adını yazma, okuma, görsel algı, planlama-dikkat gibi alanlarda olduğu; aynı konu bağlamında iki ve üstü çalışmanın olmadığı ve bunun sebebinin de yapılan çalışmaların az olmasıdır. Yine çalışmalarda hedeflenen bağımlı değişkenleri öğretmek amacıyla uygulanan ve bağımlı değişken üzerinde etkisine bakılmak üzere uygulanan, bilgisayar destekli eğitim programları, Frostig görsel algı ve PASS (planning-attention-simultaneous-successive) gibi eğitim programları, diyagram yöntemi, doğrudan öğretim eşzamanlı ipucuyla öğretim ve kapat-kopyala-yapıştır gibi bağımsız değişkenlerin olduğu birer çalışma olduğu görülmüştür. Bu nedenle, Türkiye'de öğrenme güçlüğü olan bireylerin okuma, yazma, matematik vb. alanlarda yaşadıkları güçlükleri gidermek için aynı konularda birden çok öğretimin yapılması ve bu aynı bağımlı değişkenlerin öğretimi için bağımsız değişken olarak aynı strateji, yöntem, teknik ve eğitim programlarının kullanılmasının, etkili ya da verimli olan strateji, yöntem, teknik ve eğitim programlarının belirlenmesine ve bunların daha çok kullanılmasına yardımcı olacağı ve bunun da öğrenme güçlüğü olan bireylerin ihtiyaç duydukları alanlarda gelişim göstermelerine katkı sağlayacağı düşünülmektedir. 
Yurtdışında öğrenme güçlüğü olan ve/veya öğrenme güçlüğü riski taşıyan bireylerle matematik, okuma-okuduğunu anlama ve yazma konularında deneysel olarak yapılmış, öğretimde teknolojinin kullanıldığı deneysel araştırmalar ve 16 yaş ve üstü ortaöğretim-üniversite eğitimi alan öğrenme güçlüğü olan bireylerle yapılmış olan çalışmalar betimsel olarak analiz edilebilir.

\section{Kaynakça}

American Psychiatric Assosication. (2013). Diagnostic and Statistical Manual of Mental Disorders (DSM-5) (5th ed.). Arlington, VA: American Psyhiatric Publishing.

Arslan, D. ve Dirik, M. Z. (2008). Ilköğretim ikinci sınıf öğrencilerinin okuma güçlüklerini gidermede okumayı geliştirici duyuşsal yaklaşımın etkisi. Uludağ Üniversitesi Eğitim Fakültesi Dergisi, 21(1), 1-18. http://dergipark.gov.tr/uefad/issue/16687/173402

Aslan, K. (2015). Özgül öğrenme güçlüğünün erken dönem belirtileri ve erken müdahale uygulamalarına dair derleme. Hacettepe Üniversitesi Sağlık Bilimleri Fakültesi Dergisi, 1 (2), 577-588. http://dergipark.gov.tr/husbfd/issue/7893/103918

Balıkçı, Ö., S., (2017). Erken Çocukluk Dönemi Öğrenme Güçlüğü Belirtileri. M.A. Melekoğlu, O. Çakıroğlu (Ed.), Özel Öğrenme Güçlüğü Olan Çocuklar içinde (s.75-100). Ankara:Vize yayıncılık

Balıkçı, Ö., S., (2017). Öğrenme Güçlüğü ve Okuma. M.A. Melekoğlu, O. Çakıroğlu (Ed.), Özel Öğrenme Güçlüğü Olan Çocuklar içinde (s.181-200). Ankara:Vize yayıncılık

Çıkılı, Y., Alegöz, A., Bala, M. (2017). Öğrenme Güçlükleri için Okumayı Değerlendirme ve Geliştirme. (1. Baskı), Ankara: Nobel Akademik Yayıncllık

Doğan, H. (2012). Özel Öğrenme Güçlüğü Riski Taşıyan 5-6 Yaş Çocukları için Uygulanan Erken Müdahale Eğitim Programının Etkisinin İncelenmesi. (Yayınlanmamış doktora tezi). Marmara Üniversitesi/Eğitim Bilimleri enstitüsü, İstanbul.

Doğmaz, S. (2016). Özel Öğrenme Güçlüğü Olan Öğrencilerin İki Basamaklı Matematiksel Rutin Problem Çözme Performanslarını Geliştirmede Diyagram Yöntemi Kullanımının Etkililiği. (Yayınlanmamış yüksek lisans tezi). Dokuz Eylül Üniversitesi/Eğitim Bilimleri Enstitüsü, İzmir.

İlik, Ş. Ş. (2009). Hafif Düzeyde Öğrenme Güçlüğüne Sahip Öğrencilerde Doğrudan Öğretim Yönteminin Fen ve Teknoloji Dersine İlişkin Kavramların Öğretiminde Etkililiğinin Değerlendirilmesi. (Yayınlanmamış yüksek lisans tezi). Selçuk Üniversitesi/Sosyal Bilimler Enstitüsü, Konya.

İlker, Ö., A. (2017). Öğrenme Güçlüğü ve Yazılı Anlatım. M.A. Melekoğlu, O. Çakıroğlu (Ed.), Özel Öğrenme Güçlüğü Olan Çocuklar içinde (s.201243). Ankara:Vize yayıncılık

Illker, Ö., \& Melekoğlu, M. A. (2017). İlköğretim döneminde özel öğrenme güçlüğü olan öğrencilerin yazma becerilerine ilişkin çalışmaların incelenmesi. Ankara Üniversitesi Eğitim Bilimleri Fakültesi Özel Eğitim Dergisi, 18(3), 443-469. http://dergipark.gov.tr/download/article-file/374306

Kançeşme, C. (2015). Özel Öğrenme Güçlüğü Olan Öğrencilere Sayıların İngilizce Yazımının Öğretiminde Eşzamanlı İpucu ile Kapat-Kopyala-Karşılaştı Öğretim Yöntemlerinin Etkililiklerinin Karşılaştııılması. (Yayınlanmamış yüksek lisans tezi). Abant İzzet Baysal Üniversitesi/Eğitim Bilimleri Enstitüsü, Bolu.

Kirk, S. A. (1977). Specifik learning diasabilities. Journal of Clinical Child Psychology, pp. 23-26. https://doi.org/10.1080/15374417709532776

Mutlu, Y. (2016). Bilgisayar Destekli Öğretim Materyallerinin Matematik Öğrenme Güçlüğü Yaşayan Öğrencilerin Sayı Algılama Becerileri Üzerindeki Etkilerinin İncelenmesi. (Yayınlanmamış doktora tezi). Atatürk Üniversitesi/Eğitim Bilimleri Enstitüsü, Erzurum.

Özat, N. E. (2010). Öğrenme Güçlüğü Yaşayan Çocuklarda Frostig Görsel Algı Eğitim Programının Etkisi. (Yayınlanmamış yüksek lisans tezi). Abant İzzet Baysal Üniversitesi/Sosyal Bilimler Enstitüsü, Bolu.

Özbek, A. B. (2015). Okuma güçlüğü müdahalelerinde teknoloji kullanımı. Journal of Education \& Special Education Technology. 1(1), 48-53. https://www.researchgate.net/publication/289252976_Okuma_Guclugu_Mudahalelerinde_Teknoloji_Kullanimi

Özbek, A. B. (2014). Öğrenme Güçlüğü Olan Öğrencilerin Okuma Akıcılığını Geliştirmede Tablet Bilgisayar Destekli Sağaltım Programının Etkililiği. (Yayınlanmamış yüksek lisans tezi). Dokuz Eylül Üniversitesi/Eğitim Bilimleri Enstitüsü, İzmir.

Özel Eğitim Hizmetleri Yönetmeliği, (2006). http://www.resmigazete.gov.tr/eskiler/2006/05/20060531-2.htm

Özkardeş, O. (2012). Türkiye' de özel öğrenme güçlüğüne ilişkin yapılan uygulamalar, İstanbul Ticaret Üniversitesi Sosyal Bilimler Dergisi, 11(21), 25-38. https://core.ac.uk/download/pdf/53032548.pdf

Palut, B. (2016). Okuma ve Dil Sanatlarının Öğrenme Özellikleri. H. Sarı (Çev. Ed.), Öğrenme Güçlüğü Olan Bireyler ve Eğitimleri içinde (s.179216). Ankara: Nobel Akademi Yayıncılık

Tuğrul-Kalaç, E. (2017). Öğrenme Güçlüğü ve Matematik. M.A. Melekoğlu, O. Çakıroğlu (Ed.), Özel Öğrenme Güçlüğü Olan Çocuklar içinde (s.245-280). Ankara:Vize yayıncılık

Ün, D. (2009). Özel Öğrenme Güçlüğü Yaşayan Öğrencilere Yönelik Bilişsel Müdahale Programı. (Yayınlanmamış yüksek lisans tezi). İstanbul Üniversitesi/Sosyal Bilimler Enstitüsü, İstanbul.

Yangın, S. ve Sidekli, S. (2006). Okuma güçlüğü yaşayan öğrencilerin kelime tanıma becerilerinin geliştirilmesine yönelik bir uygulama. Muğla Üniversitesi Sosyal Bilimler Dergisi, 16 (1), 1-17. http://dergipark.gov.tr/musbed/issue/23524/250641

Yüksek Öğretim Kurulu, Ulusal Tez Merkezi. (2018). https://tez.yok.gov.tr/ 